OPEN ACCESS

Edited by:

Ming Li,

Osaka University, Japan

Reviewed by:

Matteo Pirro,

University of Perugia, Italy

Philippe Bourin,

Univercell-Biosolutions, France

Carolina Balbi,

Cardiocentro Ticino, Switzerland

${ }^{*}$ Correspondence:

Chunying Li

cli19@gsu.edu

Specialty section:

This article was submitted to

Stem Cell Research,

a section of the journal

Frontiers in Cell and Developmental

Biology

Received: 13 June 2018

Accepted: 28 September 2018

Published: 18 October 2018

Citation:

Hou Y and Li C (2018)

Stem/Progenitor Cells and Their

Therapeutic Application

in Cardiovascular Disease.

Front. Cell Dev. Biol. 6:139.

doi: 10.3389/fcell.2018.00139

\section{Stem/Progenitor Cells and Their Therapeutic Application in Cardiovascular Disease}

\author{
Yuning Hou and Chunying Li* \\ Center for Molecular and Translational Medicine, Georgia State University, Atlanta, GA, United States
}

Cardiovascular disease is the leading cause of death in the world. The stem/progenitor cell-based therapy has emerged as a promising approach for the treatment of a variety of cardiovascular diseases including myocardial infarction, stroke, peripheral arterial disease, and diabetes. An increasing number of evidence has shown that stem/progenitor cell transplantation could replenish damaged cells, improve cardiac and vascular functions, and repair injured tissues in many pre-clinical studies and clinical trials. In this review, we have outlined the major types of stem/progenitor cells, and summarized the studies in applying these cells, especially endothelial stem/progenitor cells and their derivatives, in the treatment of cardiovascular disease. Here the strategies used to improve the stem/progenitor cell-based therapies in cardiovascular disease and the challenges with these therapies in clinical applications are also reviewed.

Keywords: stem cells, progenitor cells, endothelial progenitor cells, cardiovascular disease, cell therapy

\section{INTRODUCTION}

According to the recent study, cardiovascular diseases (CVDs) are highly prevalent globally and produce immense health and economic burdens in the United States and the world (Writing Group Members et al., 2016). The pathophysiological and physiological changes accompanied with vascular aging lead to compromised cardiovascular functions and elevated risks of CVDs including atherosclerosis, hypertension, and diabetes in elder population (El Assar et al., 2012). Peripheral arterial disease (PAD) and coronary heart disease including myocardial infarction (MI) account for most of all CVDs (Writing Group Members et al., 2016). Except for genetic defects, most CVDs can be attributed to unhealthy lifestyle factors such as high fat diet, high salt diet, and smoking (Writing Group Members et al., 2016).

With the advances in our understanding of the underlying mechanisms of CVDs, breakthrough has been achieved in diagnosis and intervention, such as percutaneous coronary intervention (PCI), coronary artery bypass grafting (CABG), and heart transplantation. However, to some degree, these approaches can only delay the heart failure (Trevelyan et al., 2005). This burden of disease has driven the investigation of stem/progenitor cell-based therapy for the CVDs. Experimental studies suggested that administration of endogenous stem/progenitor cells may contribute to functional regeneration of infarcted myocardium and repair damaged/injured endothelial cells (Xu, 2006). Over the past decades, stem or progenitor cell-based therapy has emerged as a promising approach for the treatment of various CVDs, such as MI, heart failure, and PAD (Wollert and Drexler, 2010). The efficacy of various stem/progenitor cells including endothelial progenitor cells (EPCs) (Leistner et al., 2011), hematopoietic stem cells (HSCs) (Perin et al., 2012), cardiac stem cells 
(CSCs) (Makkar et al., 2012), and bone-marrow derived mononuclear cells (MNCs) (Wollert et al., 2017) in treating CVDs has already been evaluated in clinical trials. The potential therapeutic applications of stem/progenitor cells, such as embryonic stem cells (ESCs) (Shiba et al., 2012) and mesenchymal stem cells (MSCs) (Min et al., 2002), have been investigated in experimental and preclinical studies. As endothelial dysfunction is one of the major problems for CVDs, there is an increasing interest and ongoing efforts to study EPCs and other stem/progenitor cell-derived endothelial cells as potential sources for cell therapy (Reed et al., 2013). Here we summarize the studies using endothelial stem/progenitor cells and their derivatives, or sometimes oversimplified as "EPCs," in the treatment of CVDs.

\section{CELL SPECTRUM OF STEM/PROGENITOR CELL DERIVED ENDOTHELIAL CELLS}

\section{MSCs}

Mesenchymal stem cells were originally identified and characterized by Friedenstein et al. (1976) in the 1970s. MSCs have been found in multiple organs throughout the body including bone marrow (BM), umbilical cord, placenta, dental pulp, and adipose tissue and their characteristics have been reviewed recently (Karantalis and Hare, 2015). MSCs derived from BM, adipose tissue, and umbilical cord have been widely used in preclinical and clinical trials. It has been reported that adipose-derived stromal/stem cells (ASCs) possess strong angiogenic potential and paracrine activities (Bura et al., 2014). Early phase clinical trials have shown that ASC transplantation has improved rest pain, ulcer surface, walking distance, pain-free walking time, and transcutaneous oxygen pressure in PAD patients (Lee et al., 2012). MSCs possess several advantages as one of the promising candidates for stem/progenitor cell-based therapy: First, MSCs are easy to isolate and expand; Second, MSCs can secrete growth factors or directly differentiate into vascular cells or myocytes to contribute to arteriogenesis and angiogenesis (Wingate et al., 2014); Third, MSCs hold an immunoregulatory capacity and immunosuppressive effect indicating their potential of autotransplantation (De Miguel et al., 2012). These advantages enable MSCs to improve the neovascularization and blood flow in PAD and $\mathrm{MI}$ related ischemic tissues (Iwase et al., 2005; Gnecchi et al., 2006). Though with limitations such as the low retention and survival of transplanted MSCs (Muller-Ehmsen et al., 2006), the cell pretreatment and genetic engineering approaches will provide a promising future for MSC based therapy (Li et al., 2007).

\section{iPSCs}

Induced pluripotent stem cells (iPSCs), which exhibit pluripotent differentiation and self-renewal potential that are similar to that of ESCs, was originally reported by Takahashi et al. (2007). By introducing four essential transcription factors (Oct3/4, Sox2, c-Myc, and Klf4) into fibroblasts, Yamanaka and colleagues have reprogrammed the cells into pluripotent stem cells. Using this technique, they and others have shown that iPSCs can be differentiated into endothelial cells (Sivarapatna et al., 2015). Studies have shown that iPSC derived endothelial cells are capable of angiogenesis and reendothelialization to form vascular networks in vitro (Suzuki et al., 2012). Preclinical studies also showed the promising therapeutic potential of iPSCs (Gu et al., 2012). Although teratoma formation (Seminatore et al., 2010) and the potential of tumorigenicity of transplanted cells (Yamanaka, 2012) are challenges in the clinical applications of iPSCs, iPSCs generated via non-genetic based techniques (Rhee et al., 2011) will improve the safety to overcome those disadvantage. Because iPSCs can be derived from mature somatic cells, the cell source is easy to obtain. Furthermore, the source of iPSCs can be autologous, so there is no need for immunosuppression when delivery. These features make iPSCs an attractive cell source for regenerative medicine.

\section{AFSCs}

Amniotic fluid derived stem cells (AFSCs) have been documented to be a special type of stem cells that possess a comprehensive multi-differentiation potential (Romani et al., 2015). Preclinical studies have shown that AFSCs can differentiate into vascular cell lineages to improve blood supply (Maraldi et al., 2013) or promote the regeneration of myocytes through their paracrine effects (Bollini et al., 2011). Besides, AFSCs also possess several advantages which make them a potential therapeutic approach. First, ASFCs are easy to be obtained from amniocentesis specimens which are used for prenatal genetic diagnosis. Second, the obtained ASFCs, which are c-Kit positive, can be readily expanded ex vivo with a doubling time of 36 h. Third, ASFCs can be differentiated into cell types including adipogenic, osteogenic, myogenic, endothelial, neuronal, and hepatic lineages (Romani et al., 2015). More importantly, it has been recently reported that AFCSs can induce immunosuppressive activities of regulatory $\mathrm{T}$ cells (Tregs) to promote allograft survival in animal models of allogeneic transplantation (Romani et al., 2015). With more extensive studies being conducted, detailed molecular mechanisms have been proposed. A most recent study has demonstrated that several properties of AFSCs including immunoregulatory functions, cell differentiation toward multiple lineages, and migratory potency are regulated by sphingosine-1phosphate (S1P) (Romani et al., 2018).

\section{MNCs}

Mononuclear cells, which can be isolated from BM and peripheral blood, are extensively studied in tissue engineering and regenerative medicine. They can be harvested from BM and peripheral blood by density gradient centrifugation with no need for ex vivo expansion. Moreover, MNCs are heterogenic which contain several types of stem/progenitor cells such as MSCs and EPCs. These cells are capable of differentiating into vascular and/or myocytes, or secrete growth factors improving the regeneration of injured tissues (Karantalis et al., 2012). These features allow quick autologous application after harvest, so MNCs are widely used as therapeutic cells in CVDs (Goumans et al., 2014). However, recent systemic review and meta-analysis 
of the clinical efficacy of MNC transplantation only reveal modest clinical benefit. For PAD, improvements could be achieved in wound healing, amputation-free survival, pain-free walking, resting pain, and ulcer healing, but administration of MNCs could not improve the primary end-point of limb amputation compared with placebo (Rigato et al., 2017; Qadura et al., 2018). Another recent meta-analysis consisting of 2037 patients with acute MI has shown that MNC therapy only modestly improved left ventricular ejection fraction (LVEF) and infarct size (de Jong et al., 2014). Despite the publication bias and possible lack of statistical power, several aspects during MNC administration could be improved to achieve better clinical results, for instance, refinement of cell delivery strategy to enhance cell survival and function. Recent progress made in the decelluarized scaffolds, which create the scaffolds enriched in structural extracellular matrix components that support cell attachment and infiltration in vitro and in vivo (Crapo et al., 2011), stimulates great interest. Moreover, current genomic sequencing and proteomic techniques could also be utilized to identify essential pathways to improve the survival and function of transplanted cells.

\section{CPCs}

After the introduction of cardiac progenitor cells (CPCs), researchers began to determine the possibility of the experimental and clinical usage of CPCs as a potential therapeutic agent. CPCs are a group of heterogeneous cells residing in the cardiac tissue (Senyo et al., 2013). After the identification of CPCs, researchers have discovered different cardiac resident cellular pools in human or murine heart, showing a variety of stem cell markers, including c-Kit ${ }^{+}$, stem cell antigen- $1^{+}\left(\mathrm{Sca}-1^{+}\right)$, Islet $1^{+}\left(\right.$Isl- $\left.1^{+}\right)$, stagespecific embryonic antigen- $1^{+}\left(\right.$SSEA- $\left.11^{+}\right)$, cardiospheres (CS), cardiospheres-derived (CD), and side population (SP), which has recently been reviewed extensively by Bianconi et al. (2017, 2018). CPCs can self-renew, and they can also differentiate into three different cardiac cell types including cardiomyocytes, smooth muscle cells and endothelial cells (Sturzu and Wu, 2011; Bianconi et al., 2018). It has been reported that embryonic heart tubes derived CPCs can differentiate into pacemaker-like cells through endothelin-1 factor involved signaling (Zhang et al., 2012). Recently, engineered cardiac pacemakers containing both CPC-derived pacemaker-like cells and EPCs have demonstrated the promising potential to ameliorate sinus node malfunction (Zhang et al., 2017). Meanwhile, accumulating studies have shown that CPCs promote cardiac tissue restoration after CVD by releasing anti-apoptotic and angiogenic signals in a paracrine manner (Ibrahim et al., 2014). It has been shown that CPC-derived exosomes promoted angiogenesis, cardiomyocyte survival and proliferation, and reduced cell apoptosis (Marban, 2014). Analysis of CPC-based clinical trials has revealed that patients suffering from heart-related diseases benefit from CPCbased therapy (Bianconi et al., 2018).

\section{EPCs}

Asahara et al. (1997) initially isolated angioblasts with endothelial lineage potential from human peripheral blood and named them "EPCs." They also found that these EPCs can differentiate into endothelial-like cells in vitro and participate in neovascularization in animal models of ischemia. Later, EPCs have been shown to migrate to peripheral blood from $\mathrm{BM}$ to participate in repairing dysfunctional endothelia and decreasing cardiovascular risk factor related endothelial injury by directly infusing into and forming new vessels or secreting pro-angiogenic growth factors or cytokines (Asahara et al., 2011). Although an increasing number of reports have been documented to identify EPCs, there is still a lack of unambiguous and consistent definition of EPCs. Generally, EPCs are a group of cells which are characterized by positively expressing VEGFR2/Flk1, CD133/AC133, and CD34 at early stages; while at late stages when they gradually differentiate into endothelial cells, EPCs start to express endothelial markers including VE-cadherin, vWF, and endothelial nitric oxide synthase (eNOS) (Ambasta et al., 2017). Accumulating studies indicates that early EPCs promotes angiogenesis in a paracrine manner, and the late stage EPCs directly participate in endothelial neovascularization (Ambasta et al., 2017).

\section{EPC BASED CELL THERAPY IN CVDS}

It is well-known that the integrity and functional activity of the endothelial monolayer are maintained by replication and migration of neighboring mature endothelial cells under physiological conditions. However, a series of clinical and preclinical studies have provided the evidence that in conditions of endothelial injury, regeneration of endothelial monolayer is assisted by EPCs homing to the artery wall. A critical early event in CVDs is endothelial dysfunction, which is perpetuated during the exposure of cardiovascular risk factors including hypercholesterolemia, metabolic syndrome, diabetes, hypertension, dyslipidemia, aging, and smoking. It has been reported that the number of circulating EPCs is inversely correlated with the presence of cardiovascular risk factors (Mannarino and Pirro, 2008; Pirro et al., 2015). Over the last two decades, extensive investigations in clinical and preclinical studies indicate that EPCs are a promising option to treat CVDs such as MI. The findings of EPC cell therapy for MI in animal studies have been summarized in Table 1. Accumulating clinical trials have evaluated the safety and efficacy of EPCs for CVDs treatment, as summarized in Table 2. As revealed in Table 2, the clinical outcomes of the stem/progenitor cellbased therapy only achieved modest benefits, so more strategies should be employed to improve the stem/progenitor cell-based therapy.

\section{EPC BASED THERAPY FOR ISCHEMIC VASCULAR DISEASES}

The therapeutic efficacy of EPCs was not only documented in the studies of CVDs but also in the peripheral artery diseases (PAD). PAD is commonly referred to as the ischemia of limbs associated with atherosclerotic occlusion (Ouriel, 2001). Peripheral arteries supply oxygenated blood and nutrients to the legs and feet and narrowing of these arteries results 
TABLE 1 | Stem cell/EPC therapy in animal models of MI.

\begin{tabular}{|c|c|c|c|c|}
\hline Animal model & Transplanted cell type & Delivery strategy & Outcomes & Reference \\
\hline Mouse MI & Mouse BM-EPCs & Intravenous injection & $\begin{array}{l}\text { EPC incorporated into neovascularization } \\
\text { foci at infarct border }\end{array}$ & Asahara et al., 1999 \\
\hline Mouse Ml & $\begin{array}{l}\text { Bone marrow derived mouse } \\
\text { Lin- c-kit+ }\end{array}$ & Intramyocardial injection & $\begin{array}{l}\text { Newly formed myocardium occupied } 68 \% \\
\text { of the infarcted portion of the ventricle were } \\
\text { observed }\end{array}$ & Orlic et al., 2003 \\
\hline Rat Ml & Human peripheral blood EPCs & Intravenous injection & $\begin{array}{l}\text { EPCs incorporated into foci of } \\
\text { neovascularization, smaller ventricular } \\
\text { dimensions and ventricular scarring; } \\
\text { increased fractional shortening, capillary } \\
\text { density }\end{array}$ & Kawamoto et al., 2001 \\
\hline Rat Ml & $\begin{array}{l}\text { Human peripheral blood } \\
\text { CD34 }^{+} \text {cells }\end{array}$ & Tail vein injection & $\begin{array}{l}\text { Decreased apoptosis of hypertrophied } \\
\text { myocytes in the peri-infarct region, reduced } \\
\text { collagen deposition, increased myocardium } \\
\text { survival and cardiac function }\end{array}$ & Kocher et al., 2001 \\
\hline Pig Ml & Pig MNCs & Trans-endocardial injection & $\begin{array}{l}\text { Increased systolic function, regional blood } \\
\text { flow, collateral vessel formation, and } \\
\text { decreased ischemic area }\end{array}$ & Kamihata et al., 2002 \\
\hline Pig Ml & Pig MSCs & Intramyocardial injection & $\begin{array}{l}\text { Decreased degree of contractile } \\
\text { dysfunction and wall thinning }\end{array}$ & Shake et al., 2002 \\
\hline Rat Ml & Rat MSCs transduced Akt1 & Intramyocardial injection & $\begin{array}{l}\text { Inhibited the process of cardiac remodeling, } \\
\text { restored myocardial volume }\end{array}$ & Mangi et al., 2003 \\
\hline Rat Ml & $\begin{array}{l}\text { Human peripheral blood } \\
\text { CD34 }^{+} \text {angioblasts (EPCs) }\end{array}$ & Tail vein injection & $\begin{array}{l}\text { Dose-dependent neovascularization with } \\
\text { development of larger-sized capillaries; } \\
\text { improve cardiac function through inhibiting } \\
\text { apoptosis and promoting proliferation of } \\
\text { cardiomyocytes }\end{array}$ & Schuster et al., 2004 \\
\hline Rat Ml & Rat ASCs & $\begin{array}{l}\text { Sheet technology (monolayered } \\
\text { cell graft placed on the surface } \\
\text { of the anterior scar) }\end{array}$ & $\begin{array}{l}\text { ASCs reversed wall thinning in scar area } \\
\text { and improve cardiac function. ASCs } \\
\text { triggers angiogenesis and differentiate into } \\
\text { vessels and cardiomyocytes }\end{array}$ & Miyahara et al., 2006 \\
\hline Rat Ml & $\begin{array}{l}\text { Rat umbilical cord blood } \\
\text { CD133 }^{+} \text {cells }\end{array}$ & Intravenous infusion & $\begin{array}{l}\text { Scar thinning and LV systolic dilatation were } \\
\text { prevented }\end{array}$ & Leor et al., 2006 \\
\hline Pig Ml & Pig CD34+ & Intracoronary injection & $\begin{array}{l}\text { Improved cardiac repair and collateral } \\
\text { vessel formation }\end{array}$ & Zhang et al., 2007 \\
\hline Rat Ml & $\begin{array}{l}\text { Human EPCs accompanied } \\
\text { with SDF-1 }\end{array}$ & Intramyocardial injection & $\begin{array}{l}\text { Improved fractional shorting, left ventricular } \\
\text { developing pressure, coronary flow rates, } \\
\text { and neovascularization. Reduced the } \\
\text { number of inflammatory cells and the rate } \\
\text { of apoptotic cells }\end{array}$ & Schuh et al., 2008 \\
\hline Mouse Ml & Human myoendothelial cells & Intramyocardial injection & $\begin{array}{l}\text { Improved left ventricular function. Increased } \\
\text { angiogenesis. Stimulated proliferation and } \\
\text { survival cardiomyocytes. Reduced scar } \\
\text { tissue }\end{array}$ & Okada et al., 2008 \\
\hline Rat Ml & $\begin{array}{l}\text { ECM scaffold supplemented } \\
\text { with EPCs primed with SDF-1 }\end{array}$ & $\begin{array}{l}\text { Sutured to the anterolateral left } \\
\text { ventricular wall }\end{array}$ & $\begin{array}{l}\text { Increased VEGF level, vessel density, } \\
\text { microvascular perfusion, vasculogenic } \\
\text { response, and decreased scar formation }\end{array}$ & Frederick et al., 2010 \\
\hline Rat Ml & $\begin{array}{l}\text { Rat peripheral blood EPCs } \\
\text { transduced with IGF-1 }\end{array}$ & Intramyocardial injection & $\begin{array}{l}\text { Increased cardiac function, cardiomyocyte } \\
\text { proliferation, and capillary density, } \\
\text { decreased cardiac apoptosis }\end{array}$ & Sen et al., 2010 \\
\hline Pig Ml & Human embryonic stem cells & $\begin{array}{l}\text { Fibrin-cell path applied to the } \\
\text { LV anterior wall of the Ml area }\end{array}$ & $\begin{array}{l}\text { Improved left ventricular function and } \\
\text { neovascularization }\end{array}$ & Xiong et al., 2011 \\
\hline
\end{tabular}

in PAD. The most common symptom of PAD is the pain with walking which is also known as intermittent claudication (Ouriel, 2001). Critical limb ischemia (CLI) is the most severe clinical manifestation of PAD affecting a limb, if not interrupted, CLI could lead to ischemic ulcerations or even gangrene (Ouriel, 2001). In preclinical studies, the most adopted animal model is the hindlimb ischemia model (HLI)
(Niiyama et al., 2009). In the HLI model, the femoral artery is ligated to reduce the blood supply to the lower leg which induces the angiogenesis to compensate for the reduced blood flow (Limbourg et al., 2009). The therapeutic efficacy of EPCs have been evaluated by this model by many groups, and Table 3 summarizes the preclinical animal studies of EPC cell therapy for PAD. 
TABLE 2 | Stem/progenitor cell/EPC therapy in clinical studies of CVDs.

\begin{tabular}{|c|c|c|c|c|c|}
\hline Trial design & Disease & Cell type & Delivery strategy & Outcomes & Reference \\
\hline $\begin{array}{l}22 \text { Bilateral ischemia } \\
\text { patients, } 25 \text { unilateral } \\
\text { ischemia patients, } \\
\text { within-patient controls }\end{array}$ & CLI & $\begin{array}{l}\text { MNCs derived from BM } \\
\text { or peripheral blood (PB) }\end{array}$ & Intramuscular injection & $\begin{array}{l}\text { Improved transcutaneous } \\
\text { oxygen pressure (TcPO2), } \\
\text { rest pain, pain-free walking } \\
\text { time, and ankle-brachial } \\
\text { index (ABI) }\end{array}$ & $\begin{array}{l}\text { Tateishi-Yuyama } \\
\text { et al., } 2002\end{array}$ \\
\hline 7 Patients, no controls & CLI & BM derived MNCs & Intramuscular injection & $\begin{array}{l}\text { Improved } \mathrm{ABI}, \mathrm{TCPO} 2 \text {, } \\
\text { pain-free walking time, and } \\
\text { leg blood flow }\end{array}$ & Higashi et al., 2004 \\
\hline 6 Patients, no controls & $\begin{array}{l}\text { Acute myocardial } \\
\text { infarction (AMI) }\end{array}$ & PB CD34+ cells & Intracoronary injection & $\begin{array}{l}\text { Improved wall motion score } \\
\text { index }\end{array}$ & Blocklet et al., 2006 \\
\hline $\begin{array}{l}44 \text { Cell-injected } \\
\text { patients, } 22 \text { control }\end{array}$ & AMl & BM-MNCs & Intracoronary injection & $\begin{array}{l}\text { Increased LVEF and peak } \\
\text { systolic velocities the } \\
\text { infarcted wall longitudinal } \\
\text { contraction }\end{array}$ & Meluzin et al., 2006 \\
\hline $\begin{array}{l}41 \text { Cell-injected } \\
\text { patients, } 45 \text { control }\end{array}$ & $\begin{array}{l}\text { ST-segment elevation } \\
\text { MI }\end{array}$ & BM-MNCs & Intracoronary injection & $\begin{array}{l}\text { Increased LVEF, no } \\
\text { improvement of myocardial } \\
\text { viability of infarcted area }\end{array}$ & Cao et al., 2009 \\
\hline $\begin{array}{l}7 \text { Patients, } \\
\text { non-randomized } \\
\text { control }\end{array}$ & Anterior Ml & PB CD34 ${ }^{+}$cells & $\begin{array}{l}\text { Transcoronary, } \\
\text { intracoronary infusion }\end{array}$ & $\begin{array}{l}\text { Decreased end-systolic } \\
\text { volume }\end{array}$ & $\begin{array}{l}\text { Dedobbeleer et al., } \\
2009\end{array}$ \\
\hline 7 Patients, no controls & $\mathrm{AMI}$ & PB CD34 ${ }^{+}$cells & Intracardiac infusion & $\begin{array}{l}\text { Increased LVEF, } \\
\text { vascularization, and the } \\
\text { regeneration of myocardial } \\
\text { structure }\end{array}$ & $\begin{array}{l}\text { Pasquet et al., } \\
2009\end{array}$ \\
\hline 28 Patients, no controls & CLI & $\mathrm{CD}_{34}{ }^{+} \mathrm{CD}_{133^{+}}$EPCs & Intramuscular injection & $\begin{array}{l}\text { Improved limb salvage rate } \\
\text { and attenuated pain scale }\end{array}$ & $\begin{array}{l}\text { Lara-Hernandez } \\
\text { et al., } 2010\end{array}$ \\
\hline $\begin{array}{l}25 \text { Cell-injected } \\
\text { patients, } 25 \\
\text { placebo-injected } \\
\text { patients; Randomized } \\
\text { double-blinded trial }\end{array}$ & $\begin{array}{l}\text { Chronic myocardial } \\
\text { ischemia }\end{array}$ & BM-MNCs & Intramyocardial infusion & $\begin{array}{l}\text { Improved E/e' and E/A } \\
\text { ratios, increased LVEF }\end{array}$ & $\begin{array}{l}\text { van Ramshorst } \\
\text { et al., } 2011\end{array}$ \\
\hline $\begin{array}{l}112 \text { Cell-injected } \\
\text { patients, } 56 \\
\text { placebo-injected } \\
\text { patients; Phase II, } \\
\text { prospective, } \\
\text { double-blinded, } \\
\text { randomized trial }\end{array}$ & Refractory angina & CD34 ${ }^{+}$cells & Intramyocardial infusion & $\begin{array}{l}\text { Improved exercise } \\
\text { tolerance }\end{array}$ & $\begin{array}{l}\text { Losordo et al., } \\
2011\end{array}$ \\
\hline $\begin{array}{l}71 \text { Cell-injected } \\
\text { patients, } 71 \\
\text { placebo-injected } \\
\text { patients; Phase III, } \\
\text { randomized, } \\
\text { double-blinded trial }\end{array}$ & $\mathrm{Ml}$ & $\mathrm{CD}_{133^{+}}$cells & Intramyocardial infusion & $\begin{array}{l}\text { Patients received CD133+ } \\
\text { cell injection had higher } \\
\text { LVEF }\end{array}$ & $\begin{array}{l}\text { Donndorf et al., } \\
2012\end{array}$ \\
\hline $\begin{array}{l}17 \text { Patients, no control, } \\
\text { Phase } 1 / / \text { I clinical trial }\end{array}$ & CLI & $\begin{array}{l}\text { Granulocyte-colony } \\
\text { stimulating factor } \\
\text { (GCSF) mobilized } \\
\text { CD34 }^{+} \text {cells }\end{array}$ & Intramuscular injection & $\begin{array}{l}\text { Improved toe brachial } \\
\text { pressure index and TcPO2, } \\
\text { pain scale, ulcer size, and } \\
\text { exercise tolerance }\end{array}$ & $\begin{array}{l}\text { Kinoshita et al., } \\
2012\end{array}$ \\
\hline 25 Patients, no control & CLI & $\begin{array}{l}\text { GCSF mobilized PB } \\
\text { CD34 }^{+} \text {cells }\end{array}$ & Intramuscular injection & $\begin{array}{l}\text { Improved pain-free walking } \\
\text { time, } \mathrm{ABI}, \mathrm{TcPO} 2 \text {, and } \\
\text { decreased pain score }\end{array}$ & Dong et al., 2013 \\
\hline $\begin{array}{l}11 \text { Patients, no control; } \\
\text { Phase II clinical trial }\end{array}$ & CLI & $\begin{array}{l}\text { GCSF mobilized PB } \\
\text { CD34 }^{+} \text {cells }\end{array}$ & Intramuscular injection & $\begin{array}{l}\text { Increased pain scale, skin } \\
\text { perfusion pressure, TcPO2, } \\
\text { total walking distance, toe } \\
\text { brachial pressure index, } \\
\text { and CLI-free ratio }\end{array}$ & Fujita et al., 2014 \\
\hline 49 Patients, no control & CLI & BM-MNCs & $\begin{array}{l}\text { Intramuscular and } \\
\text { intraarterial injection }\end{array}$ & $\begin{array}{l}\text { Limb amputations were } \\
\text { delayed; Improved ABI, rest } \\
\text { pain, and ulcer healing }\end{array}$ & Franz et al., 2015 \\
\hline
\end{tabular}


TABLE 3 | Stem cell/EPC therapy in animal studies of PAD.

\begin{tabular}{|c|c|c|c|c|}
\hline Animal model & Transplanted cell type & Delivery strategy & Outcomes & Reference \\
\hline $\begin{array}{l}\text { Mouse and } \\
\text { rabbit HLI }\end{array}$ & Human $\mathrm{CD}^{4}{ }^{+} ;$mouse Flk-1+ & Tail vein injection & $\begin{array}{l}\text { EPC incorporated into sites of active } \\
\text { angiogenesis }\end{array}$ & Asahara et al., 1997 \\
\hline Mouse HLI & Human EPC & Intracardiac injection & $\begin{array}{l}\text { Ischemic hindlimb blood flow increased, } \\
\text { capillary density increased, limb loss rate } \\
\text { decreased }\end{array}$ & Kalka et al., 2000 \\
\hline Rat HLI & Human CD34+ NMC (EPCs) & Intramuscular injection & $\begin{array}{l}\text { Neovascularization and blood flow } \\
\text { increased in ischemic hindlimb }\end{array}$ & Murohara et al., 2000 \\
\hline Mouse HLI & Human $\mathrm{CD} 4^{+}$cells & Intramuscular injection & $\begin{array}{l}\text { Blood flow restored in diabetic mice but not } \\
\text { in non-diabetic mice }\end{array}$ & Schatteman et al., 2000 \\
\hline Rabbit HLI & Rabbit BM-MNCs & Intramuscular injection & $\begin{array}{l}\text { More angiographically detectable collateral } \\
\text { vessel, improved blood perfusion }\end{array}$ & Shintani et al., 2001 \\
\hline Mouse HLI & $\begin{array}{l}\text { VEGF gene transduced Human } \\
\text { EPCs }\end{array}$ & Tail vein injection & $\begin{array}{l}\text { Neovascularization and blood flow recovery } \\
\text { improved, and limb necrosis was reduced }\end{array}$ & Iwaguro et al., 2002 \\
\hline Mouse HLI & $\begin{array}{l}\text { Human EPCs accompanied } \\
\text { with SDF-1 }\end{array}$ & $\begin{array}{l}\text { Intramuscular SDF-1 and } \\
\text { intravenous EPC injection }\end{array}$ & $\begin{array}{l}\text { Improved local accumulation of EPCs in } \\
\text { ischemic muscle, ischemic tissue perfusion, } \\
\text { and capillary density }\end{array}$ & Yamaguchi et al., 2003 \\
\hline Mouse HLI & $\begin{array}{l}\text { Human cord blood CD34+ } \\
\mathrm{KDR}^{+} \text {or } \mathrm{CD}^{+} 4^{+} \mathrm{KDR} \text {-cells }\end{array}$ & Intramuscular injection & $\begin{array}{l}\mathrm{CD} 4^{+} \mathrm{KDR}^{+} \text {cells significantly improved } \\
\text { limb salvage and neovascularization, } \\
\text { reduced endothelial cell apoptosis and } \\
\text { interstitial fibrosis compared with } \mathrm{CD}^{+} 4^{+} \\
\text {KDR-cells }\end{array}$ & Madeddu et al., 2004 \\
\hline Mouse HLI & $\begin{array}{l}\text { Human umbilical cord blood } \\
\text { CD133+ EPCs }\end{array}$ & Tail vein injection & $\begin{array}{l}\text { Increased neovascularization and improved } \\
\text { ischemic limb salvage }\end{array}$ & Yang et al., 2004 \\
\hline Rat HLI & $\begin{array}{l}\text { Human peripheral blood } \\
\text { CD133+ progenitor cells }\end{array}$ & Intramuscular injection & Increased arteriole and capillary density & Suuronen et al., 2006 \\
\hline Mouse HLI & $\begin{array}{l}\text { Human EPCs and smooth } \\
\text { muscle progenitor cells }\end{array}$ & Intravenous injection & Vessel density and foot perfusion increased & Foubert et al., 2008 \\
\hline Mouse HLI & Mouse MNCs & Intramuscular injection & $\begin{array}{l}\text { Increased blood flow ratio and capillary } \\
\text { density; improved ankle-brachial index } \\
\text { value, walking distance, pain scale, and } \\
\text { TcPO2 }\end{array}$ & Zhang et al., 2008 \\
\hline Mouse HLI & Human iPSC-ECS & Intramuscular injection & $\begin{array}{l}\text { Increased capillary density and blood } \\
\text { perfusion ratio }\end{array}$ & Rufaihah et al., 2011 \\
\hline Mouse HLI & $\begin{array}{l}\text { Human HUVECs and umbilical } \\
\text { cord MSCs }\end{array}$ & Intramuscular injection & $\begin{array}{l}\text { Blood perfusion recovered, increased } \\
\text { vessel formation }\end{array}$ & Chen et al., 2013 \\
\hline Mouse HLI & Human MNCs, ESC, and iPSC & Intramuscular injection & $\begin{array}{l}\text { Increased neovascularization and } \\
\text { decreased hindlimb ischemia }\end{array}$ & Lai et al., 2013 \\
\hline Mouse HLI & Human AFSCs & Intramuscular injection & $\begin{array}{l}\text { Increased limb salvage, limb blood } \\
\text { perfusion, and capillary and arteriole density }\end{array}$ & Liu et al., 2013 \\
\hline
\end{tabular}

\section{APPROACHES FOR ENHANCING EPC THERAPY IN DISEASES}

Although EPCs possess exciting therapeutic potency, their limited plasticity and amount in patients with ischemic cardiac or ischemic vascular disease have become the obstacle to the success in EPC therapy. It has been reported that compromised EPC availability and repair potential to regenerate the injured endothelial monolayer mainly resulted from the influence of cardiovascular risk factors such as aging, smoking, diabetes, hypertension, and hypercholesterolemia (Pirro et al., 2008, 2012). As summarized, the clinical outcome of EPC based therapy was modest, and large-scale clinical trials have not been conducted. One of the reasons is that there is a lack of suitable transplantation models. Studies in animal models suggested that BM-MNCs or EPCs could home to ischemic tissues and restore the blood supply, however, during atherosclerosis acute surgical resection has little resemblance to chronic occlusion (Qadura et al., 2018). Moreover, because of the heterogeneity between patients, in clinical trials, the selection of patient population for stem/progenitor cell-based therapy may not be optimized. These problems should be addressed before the clinical transfer of EPC based cell therapy. Therefore, an increasing number of studies have been focusing on the strategies to enhance the therapeutic efficacy of EPCs (Penn and Mangi, 2008). Various modifiers including chemokine receptors, growth factors, signaling molecules or factors, medicines, and physical exercise have been demonstrated to enhance the therapeutic effects of EPCs.

The key factors shown to enhance the cell-based therapeutics in CVDs include but not limited to: chemokine receptors such as CXCR2 (Hou et al., 2015), CXCR4 (Jujo et al., 2013), CX3CR1 (Herlea-Pana et al., 2015), CXCR7 (Zhang et al., 2014), and CCR5 (Zhang et al., 2015); growth factors and their receptors 
such as VEGF1/2/3 (Shintani et al., 2006; Smadja et al., 2007), PDGF (Rosell et al., 2013), FGF-1/2 (Rosell et al., 2013; Chien et al., 2016), and so on. Signaling molecules and factors such as eNOS/nitric oxide (Kaur et al., 2009; Cui et al., 2011), AMPactivated protein kinase (AMPK) (Wang X.R. et al., 2011), hemeoxygenase-1 (HO-1) (Sambuceti et al., 2009), and manganese superoxide dismutase (MnSOD) (Marrotte et al., 2010), have also been shown to play important roles in EPC biology. Additionally, several transcription factors signaling including Homeobox A9 (HOXA9), Akt/Forkhead box-containing protein O subfamily (Akt-FOXO), and peroxisome proliferator-activated regulator-gamma (PPAR $\gamma$ ) have been suggested to be involved in regulating the function of EPCs (Pirro et al., 2008). Moreover, many medications used for prevention of CVDs have also been shown to increase the level of EPCs such as statins (Pirro et al., 2009; Wang W. et al., 2011) and angiotensin II receptor antagonists (Pelliccia et al., 2010), etc. Wang W. et al. (2011) demonstrated that statins could improve the mobilization, derivation, and colonial growth of late outgrowth EPCs. They have also shown that pravastatin increased the capillary density in chronic myocardial ischemia by $46 \%$ in an animal model. More interestingly, it has been reported that exercise could improve the function of EPCs (Guo et al., 2017). The underlying mechanism between exercise and EPCs has mainly been linked to CXCR4 signaling, VEGF release, and nitric oxide (NO) bioavailability. VEGF has been shown to be important in angiogenesis. Studies have shown that after exercise training, the expression level of VEGF and its receptors in mice were significantly increased in post-MI. Meanwhile, the mice preconditioned with exercise expressed higher level of VEGF and its receptors compared with mice without exercise preconditioning (Wu et al., 2009). In an animal model of hypertension, exercise significantly increased EPC levels and also resulted in vascular repair in a VEGF/eNOS dependent manner (Fernandes et al., 2012). Studies also demonstrated that exercise training increased the expression level of CXCR4 and phosphorylation level of Janus kinase-2 (JAK-2) of EPCs, improved the endothelial function in vitro and reendothelialization capacity of EPCs in vivo (Xia et al., 2012).

Studies have been performed to identify the key regulators to rescue the defective functions of EPCs from patients exposed to cardiovascular risk factors such as diabetes and aging. For instance, EPC transduced with Akt/HO-1 displayed increased MI recovery in nude mice (Brunt et al., 2012). The importance of eNOS in EPC angiogenesis has also been evaluated by different groups. In a rat balloon injury model, the neointimal hyperplasia was inhibited, and vascular function was restored by transplanting eNOS overexpressed EPCs (Cui et al., 2011). Also, it has been shown that overexpressing eNOS in EPCs isolated from coronary artery disease displayed increased functions such as proliferation, differentiation, migration, and integration into tube-like structures in vitro (Kaur et al., 2009). Accumulating studies have demonstrated the importance of chemokine receptors and their cognate ligands in EPC survival and function. CXCR4 has been shown to play a critical role in EPC mobilization and angiogenesis in vivo
(Jujo et al., 2013). Recently, we have shown that CXCR2 macromolecular signaling complex is essential in mediating EPC homing and angiogenesis in vitro and in vivo (Hou et al., 2015). Therefore, approaches such as genetic modification of EPCs to modify the expression of the chemokine receptors and growth factor receptors, or pretreatment of cells with chemokines or growth factors to improve the angiogenic signaling activities, rejuvenate the cells, or enhance the survival of EPCs could be investigated to address the limitations of EPC transplantation. Moreover, the findings of the positive effects of medications and physical exercise provide additional options to enhance the efficacy of EPC therapy in cost-efficient manner.

\section{CONCLUSION}

Although clinical trials and preclinical studies have shown that EPCs and other stem cell and progenitor cells based therapy possess great therapeutic potential to improve cardiac function and blood perfusion in MI and PAD, obstacles still exist to be overcome before widespread application of EPCs in the treatment of CVD (Roediger, 1980). Cell isolation, characterization, modification, and processing strategies must be further studied and refined to achieve enhanced therapeutic efficacy. For instance, there is still lack of consistent definition of EPCs, so further study is needed to standardize methods to define EPCs, through both lineage tracing and functional analysis (Masuda et al., 2011). Meanwhile, upregulation of certain circulating progenitor cells such as circulating osteoprogenitor cells may result in vascular calcification which is a cardiovascular risk factor (Pirro et al., 2013). Moreover, the cell infusion approach, dosing regimens, as well as the cell survival after delivery are also needed to be improved to achieve optimal outcomes (Freyman et al., 2006). Due to the possibility of occurrence of teratoma formation and tumorigenesis, especially during the transplantation of iPSCs, the safety of the stem/progenitor cell-based therapies should also be monitored (Yamanaka, 2012). In summary, previous clinical trials and preclinical studies have shed light on the EPC based therapy for treating CVDs. With more efforts to understand the biology of stem/progenitor cells and continued commitment to preclinical and clinical studies, stem/progenitor cell-based therapy may present an integral part of routine regenerative therapy for CVDs in the future.

\section{AUTHOR CONTRIBUTIONS}

YH wrote the manuscript and participated in edits. CL revised and edited the entire manuscript.

\section{FUNDING}

The review and related research in our laboratory was supported in part by National Institutes of Health grant HL128647 (to CL). 


\section{REFERENCES}

Ambasta, R. K., Kohli, H., and Kumar, P. (2017). Multiple therapeutic effect of endothelial progenitor cell regulated by drugs in diabetes and diabetes related disorder. J. Transl. Med. 15:185. doi: 10.1186/s12967-017-1280-y

Asahara, T., Kawamoto, A., and Masuda, H. (2011). Concise review: circulating endothelial progenitor cells for vascular medicine. Stem Cells 29, 1650-1655. doi: $10.1002 /$ stem. 745

Asahara, T., Masuda, H., Takahashi, T., Kalka, C., Pastore, C., Silver, M., et al. (1999). Bone marrow origin of endothelial progenitor cells responsible for postnatal vasculogenesis in physiological and pathological neovascularization. Circ. Res. 85, 221-228. doi: 10.1161/01.RES.85.3.221

Asahara, T., Murohara, T., Sullivan, A., Silver, M., Van Der Zee, R., Li, T., et al. (1997). Isolation of putative progenitor endothelial cells for angiogenesis. Science 275, 964-967. doi: 10.1126/science.275.5302.964

Bianconi, V., Fallarino, F., Mannarino, M. R., Bagaglia, F., Kararoudi, M. N., Aragona, C. O., et al. (2017). Autologous cell therapy for vascular regeneration: the role of proangiogenic cells. Curr. Med. Chem. [Epub ahead of print]. doi: $10.2174 / 0929867324666171012111603$

Bianconi, V., Sahebkar, A., Kovanen, P., Bagaglia, F., Ricciuti, B., Calabro, P., et al. (2018). Endothelial and cardiac progenitor cells for cardiovascular repair: a controversial paradigm in cell therapy. Pharmacol. Ther. 181, 156-168. doi: 10.1016/j.pharmthera.2017.08.004

Blocklet, D., Toungouz, M., Berkenboom, G., Lambermont, M., Unger, P., Preumont, N., et al. (2006). Myocardial homing of nonmobilized peripheralblood CD34 + cells after intracoronary injection. Stem Cells 24, 333-336. doi: 10.1634/stemcells.2005-0201

Bollini, S., Cheung, K. K., Riegler, J., Dong, X., Smart, N., Ghionzoli, M., et al. (2011). Amniotic fluid stem cells are cardioprotective following acute myocardial infarction. Stem Cells Dev. 20, 1985-1994. doi: 10.1089/scd.2010. 0424

Brunt, K. R., Wu, J., Chen, Z., Poeckel, D., Dercho, R. A., Melo, L. G., et al. (2012). Ex vivo Akt/HO-1 gene therapy to human endothelial progenitor cells enhances myocardial infarction recovery. Cell Transplant. 21, 1443-1461. doi: $10.3727 / 096368912 X 653002$

Bura, A., Planat-Benard, V., Bourin, P., Silvestre, J. S., Gross, F., Grolleau, J. L., et al. (2014). Phase I trial: the use of autologous cultured adipose-derived stroma/stem cells to treat patients with non-revascularizable critical limb ischemia. Cytotherapy 16, 245-257. doi: 10.1016/j.jcyt.2013.11.011

Cao, F., Sun, D., Li, C., Narsinh, K., Zhao, L., Li, X., et al. (2009). Longterm myocardial functional improvement after autologous bone marrow mononuclear cells transplantation in patients with ST-segment elevation myocardial infarction: 4 years follow-up. Eur. Heart J. 30, 1986-1994. doi: 10.1093/eurheartj/ehp220

Chen, D. Y., Wei, H. J., Lin, K. J., Huang, C. C., Wang, C. C., Wu, C. T., et al. (2013). Three-dimensional cell aggregates composed of HUVECs and cbMSCs for therapeutic neovascularization in a mouse model of hindlimb ischemia. Biomaterials 34, 1995-2004. doi: 10.1016/j.biomaterials.2012.11.045

Chien, S. Y., Huang, C. Y., Tsai, C. H., Wang, S. W., Lin, Y. M., and Tang, C. H. (2016). Interleukin-1beta induces fibroblast growth factor 2 expression and subsequently promotes endothelial progenitor cell angiogenesis in chondrocytes. Clin. Sci. (Lond.) 130, 667-681. doi: 10.1042/CS20150622

Crapo, P. M., Gilbert, T. W., and Badylak, S. F. (2011). An overview of tissue and whole organ decellularization processes. Biomaterials 32, 3233-3243. doi: 10.1016/j.biomaterials.2011.01.057

Cui, B., Huang, L., Fang, Y., Guo, R., Yin, Y., and Zhao, X. (2011). Transplantation of endothelial progenitor cells overexpressing endothelial nitric oxide synthase enhances inhibition of neointimal hyperplasia and restores endotheliumdependent vasodilatation. Microvasc. Res. 81, 143-150. doi: 10.1016/j.mvr.2010. 09.009

de Jong, R., Houtgraaf, J. H., Samiei, S., Boersma, E., and Duckers, H. J. (2014). Intracoronary stem cell infusion after acute myocardial infarction: a metaanalysis and update on clinical trials. Circ. Cardiovasc. Interv. 7, 156-167. doi: 10.1161/CIRCINTERVENTIONS.113.001009

De Miguel, M. P., Fuentes-Julian, S., Blazquez-Martinez, A., Pascual, C. Y., Aller, M. A., Arias, J., et al. (2012). Immunosuppressive properties of mesenchymal stem cells: advances and applications. Curr. Mol. Med. 12, 574-591. doi: 10. 2174/156652412800619950
Dedobbeleer, C., Blocklet, D., Toungouz, M., Lambermont, M., Unger, P., Degaute, J. P., et al. (2009). Myocardial homing and coronary endothelial function after autologous blood CD34 + progenitor cells intracoronary injection in the chronic phase of myocardial infarction. J. Cardiovasc. Pharmacol. 53, 480-485. doi: 10.1097/FJC.0b013e3181a7b572

Dong, Z., Chen, B., Fu, W., Wang, Y., Guo, D., Wei, Z., et al. (2013). Transplantation of purified CD34 + cells in the treatment of critical limb ischemia. J. Vasc. Surg. 58:e403. doi: 10.1016/j.jvs.2013.01.037

Donndorf, P., Kaminski, A., Tiedemann, G., Kundt, G., and Steinhoff, G. (2012). Validating intramyocardial bone marrow stem cell therapy in combination with coronary artery bypass grafting, the PERFECT Phase III randomized multicenter trial: study protocol for a randomized controlled trial. Trials 13:99. doi: 10.1186/1745-6215-13-99

El Assar, M., Angulo, J., Vallejo, S., Peiro, C., Sanchez-Ferrer, C. F., and Rodriguez-Manas, L. (2012). Mechanisms involved in the aging-induced vascular dysfunction. Front. Physiol. 3:132. doi: 10.3389/fphys.2012.00132

Fernandes, T., Nakamuta, J. S., Magalhaes, F. C., Roque, F. R., Lavini-Ramos, C., Schettert, I. T., et al. (2012). Exercise training restores the endothelial progenitor cells number and function in hypertension: implications for angiogenesis. J. Hypertens. 30, 2133-2143. doi: 10.1097/HJH.0b013e3283588d46

Foubert, P., Matrone, G., Souttou, B., Lere-Dean, C., Barateau, V., Plouet, J., et al. (2008). Coadministration of endothelial and smooth muscle progenitor cells enhances the efficiency of proangiogenic cell-based therapy. Circ. Res. 103, 751-760. doi: 10.1161/CIRCRESAHA.108.175083

Franz, R. W., Shah, K. J., Pin, R. H., Hankins, T., Hartman, J. F., and Wright, M. L. (2015). Autologous bone marrow mononuclear cell implantation therapy is an effective limb salvage strategy for patients with severe peripheral arterial disease. J. Vasc. Surg. 62, 673-680. doi: 10.1016/j.jvs.2015.02.059

Frederick, J. R., Fitzpatrick, J. R. III, Mccormick, R. C., Harris, D. A., Kim, A. Y., Muenzer, J. R., et al. (2010). Stromal cell-derived factor-1alpha activation of tissue-engineered endothelial progenitor cell matrix enhances ventricular function after myocardial infarction by inducing neovasculogenesis. Circulation 122, S107-S117. doi: 10.1161/CIRCULATIONAHA.109.930404

Freyman, T., Polin, G., Osman, H., Crary, J., Lu, M., Cheng, L., et al. (2006). A quantitative, randomized study evaluating three methods of mesenchymal stem cell delivery following myocardial infarction. Eur. Heart J. 27, 1114-1122. doi: 10.1093/eurheartj/ehi818

Friedenstein, A. J., Gorskaja, J. F., and Kulagina, N. N. (1976). Fibroblast precursors in normal and irradiated mouse hematopoietic organs. Exp. Hematol. 4, 267274.

Fujita, Y., Kinoshita, M., Furukawa, Y., Nagano, T., Hashimoto, H., Hirami, Y., et al. (2014). Phase II clinical trial of CD34 + cell therapy to explore endpoint selection and timing in patients with critical limb ischemia. Circ. J. 78, 490-501. doi: 10.1253/circj.CJ-13-0864

Gnecchi, M., He, H., Noiseux, N., Liang, O. D., Zhang, L., Morello, F., et al. (2006). Evidence supporting paracrine hypothesis for Akt-modified mesenchymal stem cell-mediated cardiac protection and functional improvement. FASEB J. 20, 661-669. doi: 10.1096/fj.05-5211com

Goumans, M. J., Maring, J. A., and Smits, A. M. (2014). A straightforward guide to the basic science behind cardiovascular cell-based therapies. Heart 100, 1153-1157. doi: 10.1136/heartjnl-2014-305646

Gu, M., Nguyen, P. K., Lee, A. S., Xu, D., Hu, S., Plews, J. R., et al. (2012). Microfluidic single-cell analysis shows that porcine induced pluripotent stem cell-derived endothelial cells improve myocardial function by paracrine activation. Circ. Res. 111, 882-893. doi: 10.1161/CIRCRESAHA.112.269001

Guo, Y., Ledesma, R. A., Peng, R., Liu, Q., and Xu, D. (2017). The beneficial effects of cardiac rehabilitation on the function and levels of endothelial progenitor cells. Heart Lung Circ. 26, 10-17. doi: 10.1016/j.hlc.2016.06.1210

Herlea-Pana, O., Yao, L., Heuser-Baker, J., Wang, Q., Wang, Q., Georgescu, C., et al. (2015). Chemokine receptors CXCR2 and CX3CR1 differentially regulate functional responses of bone-marrow endothelial progenitors during atherosclerotic plaque regression. Cardiovasc. Res. 106, 324-337. doi: 10.1093/ $\mathrm{cvr} / \mathrm{cvv} 111$

Higashi, Y., Kimura, M., Hara, K., Noma, K., Jitsuiki, D., Nakagawa, K., et al. (2004). Autologous bone-marrow mononuclear cell implantation improves endothelium-dependent vasodilation in patients with limb ischemia. Circulation 109, 1215-1218. doi: 10.1161/01.CIR.0000121427. 53291.78 
Hou, Y., Wu, Y., Farooq, S. M., Guan, X., Wang, S., Liu, Y., et al. (2015). A critical role of CXCR2 PDZ-mediated interactions in endothelial progenitor cell homing and angiogenesis. Stem Cell Res. 14, 133-143. doi: 10.1016/j.scr. 2014.12.001

Ibrahim, A. G., Cheng, K., and Marban, E. (2014). Exosomes as critical agents of cardiac regeneration triggered by cell therapy. Stem Cell Rep. 2, 606-619. doi: 10.1016/j.stemcr.2014.04.006

Iwaguro, H., Yamaguchi, J., Kalka, C., Murasawa, S., Masuda, H., Hayashi, S., et al. (2002). Endothelial progenitor cell vascular endothelial growth factor gene transfer for vascular regeneration. Circulation 105, 732-738. doi: 10.1161/ hc0602.103673

Iwase, T., Nagaya, N., Fujii, T., Itoh, T., Murakami, S., Matsumoto, T., et al. (2005). Comparison of angiogenic potency between mesenchymal stem cells and mononuclear cells in a rat model of hindlimb ischemia. Cardiovasc. Res. 66, 543-551. doi: 10.1016/j.cardiores.2005.02.006

Jujo, K., Ii, M., Sekiguchi, H., Klyachko, E., Misener, S., Tanaka, T., et al. (2013). CXC-chemokine receptor 4 antagonist AMD3100 promotes cardiac functional recovery after ischemia/reperfusion injury via endothelial nitric oxide synthase-dependent mechanism. Circulation 127, 63-73. doi: 10.1161/ CIRCULATIONAHA.112.099242

Kalka, C., Masuda, H., Takahashi, T., Kalka-Moll, W. M., Silver, M., Kearney, M., et al. (2000). Transplantation of ex vivo expanded endothelial progenitor cells for therapeutic neovascularization. Proc. Natl. Acad. Sci. U.S.A. 97, 3422-3427. doi: 10.1073/pnas.97.7.3422

Kamihata, H., Matsubara, H., Nishiue, T., Fujiyama, S., Amano, K., Iba, O., et al. (2002). Improvement of collateral perfusion and regional function by implantation of peripheral blood mononuclear cells into ischemic hibernating myocardium. Arterioscler. Thromb. Vasc. Biol. 22, 1804-1810. doi: 10.1161/01. ATV.0000039168.95670.B9

Karantalis, V., Balkan, W., Schulman, I. H., Hatzistergos, K. E., and Hare, J. M. (2012). Cell-based therapy for prevention and reversal of myocardial remodeling. Am. J. Physiol. Heart Circ. Physiol. 303, H256-H270. doi: 10.1152/ ajpheart.00221.2012

Karantalis, V., and Hare, J. M. (2015). Use of mesenchymal stem cells for therapy of cardiac disease. Circ. Res. 116, 1413-1430. doi: 10.1161/CIRCRESAHA.116. 303614

Kaur, S., Kumar, T. R., Uruno, A., Sugawara, A., Jayakumar, K., and Kartha, C. C. (2009). Genetic engineering with endothelial nitric oxide synthase improves functional properties of endothelial progenitor cells from patients with coronary artery disease: an in vitro study. Basic Res. Cardiol. 104, 739-749. doi: 10.1007/s00395-009-0039-x

Kawamoto, A., Gwon, H. C., Iwaguro, H., Yamaguchi, J. I., Uchida, S., Masuda, H., et al. (2001). Therapeutic potential of ex vivo expanded endothelial progenitor cells for myocardial ischemia. Circulation 103, 634-637. doi: 10.1161/01.CIR. 103.5.634

Kinoshita, M., Fujita, Y., Katayama, M., Baba, R., Shibakawa, M., Yoshikawa, K., et al. (2012). Long-term clinical outcome after intramuscular transplantation of granulocyte colony stimulating factor-mobilized CD34 positive cells in patients with critical limb ischemia. Atherosclerosis 224, 440-445. doi: 10.1016/ j.atherosclerosis.2012.07.031

Kocher, A. A., Schuster, M. D., Szabolcs, M. J., Takuma, S., Burkhoff, D., Wang, J., et al. (2001). Neovascularization of ischemic myocardium by human bone-marrow-derived angioblasts prevents cardiomyocyte apoptosis, reduces remodeling and improves cardiac function. Nat. Med. 7, 430-436. doi: 10.1038/ 86498

Lai, W. H., Ho, J. C., Chan, Y. C., Ng, J. H., Au, K. W., Wong, L. Y., et al. (2013). Attenuation of hind-limb ischemia in mice with endothelial-like cells derived from different sources of human stem cells. PLoS One 8:e57876. doi: 10.1371/journal.pone.0057876

Lara-Hernandez, R., Lozano-Vilardell, P., Blanes, P., TorreguitartMirada, N., Galmes, A., and Besalduch, J. (2010). Safety and efficacy of therapeutic angiogenesis as a novel treatment in patients with critical limb ischemia. Ann. Vasc. Surg. 24, 287-294. doi: 10.1016/j.avsg.2009. 10.012

Lee, H. C., An, S. G., Lee, H. W., Park, J. S., Cha, K. S., Hong, T. J., et al. (2012). Safety and effect of adipose tissue-derived stem cell implantation in patients with critical limb ischemia: a pilot study. Circ. J. 76, 1750-1760. doi: 10.1253/ circj.CJ-11-1135
Leistner, D. M., Fischer-Rasokat, U., Honold, J., Seeger, F. H., Schachinger, V., Lehmann, R., et al. (2011). Transplantation of progenitor cells and regeneration enhancement in acute myocardial infarction (TOPCARE-AMI): final 5-year results suggest long-term safety and efficacy. Clin. Res. Cardiol. 100, 925-934. doi: 10.1007/s00392-011-0327-y

Leor, J., Guetta, E., Feinberg, M. S., Galski, H., Bar, I., Holbova, R., et al. (2006). Human umbilical cord blood-derived CD133 + cells enhance function and repair of the infarcted myocardium. Stem Cells 24, 772-780. doi: 10.1634/ stemcells.2005-0212

Li, W., Ma, N., Ong, L. L., Nesselmann, C., Klopsch, C., Ladilov, Y., et al. (2007). Bcl-2 engineered MSCs inhibited apoptosis and improved heart function. Stem Cells 25, 2118-2127. doi: 10.1634/stemcells.2006-0771

Limbourg, A., Korff, T., Napp, L. C., Schaper, W., Drexler, H., and Limbourg, F. P. (2009). Evaluation of postnatal arteriogenesis and angiogenesis in a mouse model of hind-limb ischemia. Nat. Protoc. 4, 1737-1746. doi: 10.1038/nprot. 2009.185

Liu, Y. W., Roan, J. N., Wang, S. P., Hwang, S. M., Tsai, M. S., Chen, J. H., et al. (2013). Xenografted human amniotic fluid-derived stem cell as a cell source in therapeutic angiogenesis. Int. J. Cardiol. 168, 66-75. doi: 10.1016/j.ijcard.2012. 09.072

Losordo, D. W., Henry, T. D., Davidson, C., Sup Lee, J., Costa, M. A., Bass, T., et al. (2011). Intramyocardial, autologous CD34 + cell therapy for refractory angina. Circ. Res. 109, 428-436. doi: 10.1161/CIRCRESAHA.111.245993

Madeddu, P., Emanueli, C., Pelosi, E., Salis, M. B., Cerio, A. M., Bonanno, G., et al. (2004). Transplantation of low dose CD34 + KDR + cells promotes vascular and muscular regeneration in ischemic limbs. FASEB J. 18, 1737-1739. doi: 10.1096/fj.04-2192fje

Makkar, R. R., Smith, R. R., Cheng, K., Malliaras, K., Thomson, L. E., Berman, D., et al. (2012). Intracoronary cardiosphere-derived cells for heart regeneration after myocardial infarction (CADUCEUS): a prospective, randomised phase 1 trial. Lancet 379, 895-904. doi: 10.1016/S0140-6736(12)60195-0

Mangi, A. A., Noiseux, N., Kong, D., He, H., Rezvani, M., Ingwall, J. S., et al. (2003). Mesenchymal stem cells modified with Akt prevent remodeling and restore performance of infarcted hearts. Nat. Med. 9, 1195-1201. doi: 10.1038/nm912

Mannarino, E., and Pirro, M. (2008). Endothelial injury and repair: a novel theory for atherosclerosis. Angiology 59, 69S-72S. doi: 10.1177/0003319708320761

Maraldi, T., Riccio, M., Pisciotta, A., Zavatti, M., Carnevale, G., Beretti, F., et al. (2013). Human amniotic fluid-derived and dental pulp-derived stem cells seeded into collagen scaffold repair critical-size bone defects promoting vascularization. Stem Cell Res. Ther. 4:53. doi: 10.1186/scrt203

Marban, E. (2014). Breakthroughs in cell therapy for heart disease: focus on cardiosphere-derived cells. Mayo Clin. Proc. 89, 850-858. doi: 10.1016/j. mayocp.2014.02.014

Marrotte, E. J., Chen, D. D., Hakim, J. S., and Chen, A. F. (2010). Manganese superoxide dismutase expression in endothelial progenitor cells accelerates wound healing in diabetic mice. J. Clin. Invest. 120, 4207-4219. doi: 10.1172/ JCI36858

Masuda, H., Alev, C., Akimaru, H., Ito, R., Shizuno, T., Kobori, M., et al. (2011). Methodological development of a clonogenic assay to determine endothelial progenitor cell potential. Circ. Res. 109, 20-37. doi: 10.1161/CIRCRESAHA.110. 231837

Meluzin, J., Mayer, J., Groch, L., Janousek, S., Hornacek, I., Hlinomaz, O., et al. (2006). Autologous transplantation of mononuclear bone marrow cells in patients with acute myocardial infarction: the effect of the dose of transplanted cells on myocardial function. Am. Heart. J. 152:e979-15. doi: 10.1016/j.ahj.2006. 08.004

Min, J. Y., Sullivan, M. F., Yang, Y., Zhang, J. P., Converso, K. L., Morgan, J. P., et al. (2002). Significant improvement of heart function by cotransplantation of human mesenchymal stem cells and fetal cardiomyocytes in postinfarcted pigs. Ann. Thorac. Surg. 74, 1568-1575. doi: 10.1016/S0003-4975(02)03952-8

Miyahara, Y., Nagaya, N., Kataoka, M., Yanagawa, B., Tanaka, K., Hao, H., et al. (2006). Monolayered mesenchymal stem cells repair scarred myocardium after myocardial infarction. Nat. Med. 12, 459-465. doi: 10.1038/nm1391

Muller-Ehmsen, J., Krausgrill, B., Burst, V., Schenk, K., Neisen, U. C., Fries, J. W., et al. (2006). Effective engraftment but poor mid-term persistence of mononuclear and mesenchymal bone marrow cells in acute and chronic rat myocardial infarction. J. Mol. Cell Cardiol. 41, 876-884. doi: 10.1016/j.yjmcc. 2006.07.023 
Murohara, T., Ikeda, H., Duan, J., Shintani, S., Sasaki, K., Eguchi, H., et al. (2000). Transplanted cord blood-derived endothelial precursor cells augment postnatal neovascularization. J. Clin. Invest. 105, 1527-1536. doi: 10.1172/JCI8296

Niiyama, H., Huang, N. F., Rollins, M. D., and Cooke, J. P. (2009). Murine model of hindlimb ischemia. J. Vis. Exp. 23:1035. doi: 10.3791/1035

Okada, M., Payne, T. R., Zheng, B., Oshima, H., Momoi, N., Tobita, K., et al. (2008). Myogenic endothelial cells purified from human skeletal muscle improve cardiac function after transplantation into infarcted myocardium. J. Am. Coll. Cardiol. 52, 1869-1880. doi: 10.1016/j.jacc.2008.07.064

Orlic, D., Kajstura, J., Chimenti, S., Bodine, D. M., Leri, A., and Anversa, P. (2003). Bone marrow stem cells regenerate infarcted myocardium. Pediatr. Transplant. 7(Suppl. 3), 86-88. doi: 10.1034/j.1399-3046.7.s3.13.x

Ouriel, K. (2001). Peripheral arterial disease. Lancet 358, 1257-1264. doi: 10.1016/ S0140-6736(01)06351-6

Pasquet, S., Sovalat, H., Henon, P., Bischoff, N., Arkam, Y., Ojeda-Uribe, M., et al. (2009). Long-term benefit of intracardiac delivery of autologous granulocytecolony-stimulating factor-mobilized blood CD34 + cells containing cardiac progenitors on regional heart structure and function after myocardial infarct. Cytotherapy 11, 1002-1015. doi: 10.3109/14653240903164963

Pelliccia, F., Pasceri, V., Cianfrocca, C., Vitale, C., Speciale, G., Gaudio, C., et al. (2010). Angiotensin II receptor antagonism with telmisartan increases number of endothelial progenitor cells in normotensive patients with coronary artery disease: a randomized, double-blind, placebo-controlled study. Atherosclerosis 210, 510-515. doi: 10.1016/j.atherosclerosis.2009.12.005

Penn, M. S., and Mangi, A. A. (2008). Genetic enhancement of stem cell engraftment, survival, and efficacy. Circ. Res. 102, 1471-1482. doi: 10.1161/ CIRCRESAHA.108.175174

Perin, E. C., Silva, G. V., Zheng, Y., Gahremanpour, A., Canales, J., Patel, D., et al. (2012). Randomized, double-blind pilot study of transendocardial injection of autologous aldehyde dehydrogenase-bright stem cells in patients with ischemic heart failure. Am. Heart. J. 163, 415-21, 421.e1.

Pirro, M., Bagaglia, F., Paoletti, L., Razzi, R., and Mannarino, M. R. (2008). Hypercholesterolemia-associated endothelial progenitor cell dysfunction. Ther. Adv. Cardiovasc. Dis. 2, 329-339. doi: 10.1177/1753944708094769

Pirro, M., Bocci, E. B., Di Filippo, F., Schillaci, G., Mannarino, M. R., Bagaglia, F., et al. (2012). Imbalance between endothelial injury and repair in patients with polymyalgia rheumatica: improvement with corticosteroid treatment. J. Intern. Med. 272, 177-184. doi: 10.1111/j.1365-2796.2011.02510.x

Pirro, M., Manfredelli, M. R., Schillaci, G., Helou, R. S., Bagaglia, F., Melis, F., et al. (2013). Association between circulating osteoblast progenitor cells and aortic calcifications in women with postmenopausal osteoporosis. Nutr. Metab. Cardiovasc. Dis. 23, 466-472. doi: 10.1016/j.numecd.2011.08.006

Pirro, M., Schillaci, G., Romagno, P. F., Mannarino, M. R., Bagaglia, F., Razzi, R., et al. (2009). Influence of short-term rosuvastatin therapy on endothelial progenitor cells and endothelial function. J. Cardiovasc. Pharmacol. Ther. 14, 14-21. doi: 10.1177/1074248408331021

Pirro, M., Stingeni, L., Vaudo, G., Mannarino, M. R., Ministrini, S., Vonella, M., et al. (2015). Systemic inflammation and imbalance between endothelial injury and repair in patients with psoriasis are associated with preclinical atherosclerosis. Eur. J. Prev. Cardiol. 22, 1027-1035. doi: $10.1177 / 2047487314538858$

Qadura, M., Terenzi, D. C., Verma, S., Al-Omran, M., and Hess, D. A. (2018). Concise review: cell therapy for critical limb ischemia: an integrated review of preclinical and clinical studies. Stem Cells 36, 161-171. doi: 10.1002/stem.2751

Reed, D. M., Foldes, G., Harding, S. E., and Mitchell, J. A. (2013). Stem cell-derived endothelial cells for cardiovascular disease: a therapeutic perspective. Br. J. Clin. Pharmacol. 75, 897-906. doi: 10.1111/j.1365-2125.2012.04361.x

Rhee, Y. H., Ko, J. Y., Chang, M. Y., Yi, S. H., Kim, D., Kim, C. H., et al. (2011). Protein-based human iPS cells efficiently generate functional dopamine neurons and can treat a rat model of Parkinson disease. J. Clin. Invest. 121, 2326-2335. doi: 10.1172/JCI45794

Rigato, M., Monami, M., and Fadini, G. P. (2017). Autologous cell therapy for peripheral arterial disease: systematic review and meta-analysis of randomized, nonrandomized, and noncontrolled studies. Circ. Res. 120, 1326-1340. doi: 10.1161/CIRCRESAHA.116.309045

Roediger, W. E. (1980). The colonic epithelium in ulcerative colitis: an energydeficiency disease? Lancet 2, 712-715. doi: 10.1016/S0140-6736(80)91934-0
Romani, R., Manni, G., Donati, C., Pirisinu, I., Bernacchioni, C., Gargaro, M., et al. (2018). S1P promotes migration, differentiation and immune regulatory activity in amniotic-fluid-derived stem cells. Eur. J. Pharmacol. 833, 173-182. doi: 10.1016/j.ejphar.2018.06.005

Romani, R., Pirisinu, I., Calvitti, M., Pallotta, M. T., Gargaro, M., Bistoni, G., et al. (2015). Stem cells from human amniotic fluid exert immunoregulatory function via secreted indoleamine 2,3-dioxygenase1. J. Cell Mol. Med. 19, 1593-1605. doi: $10.1111 /$ jcmm. 12534

Rosell, A., Morancho, A., Navarro-Sobrino, M., Martinez-Saez, E., HernandezGuillamon, M., Lope-Piedrafita, S., et al. (2013). Factors secreted by endothelial progenitor cells enhance neurorepair responses after cerebral ischemia in mice. PLoS One 8:e73244. doi: 10.1371/journal.pone.0073244

Rufaihah, A. J., Huang, N. F., Jame, S., Lee, J. C., Nguyen, H. N., Byers, B., et al. (2011). Endothelial cells derived from human iPSCS increase capillary density and improve perfusion in a mouse model of peripheral arterial disease. Arterioscler. Thromb. Vasc. Biol. 31, e72-e79. doi: 10.1161/ATVBAHA.111. 230938

Sambuceti, G., Morbelli, S., Vanella, L., Kusmic, C., Marini, C., Massollo, M., et al. (2009). Diabetes impairs the vascular recruitment of normal stem cells by oxidant damage, reversed by increases in PAMPK, heme oxygenase-1, and adiponectin. Stem Cells 27, 399-407. doi: 10.1634/stemcells.2008-0800

Schatteman, G. C., Hanlon, H. D., Jiao, C., Dodds, S. G., and Christy, B. A. (2000). Blood-derived angioblasts accelerate blood-flow restoration in diabetic mice. J. Clin. Invest. 106, 571-578. doi: 10.1172/JCI9087

Schuh, A., Liehn, E. A., Sasse, A., Hristov, M., Sobota, R., Kelm, M., et al. (2008). Transplantation of endothelial progenitor cells improves neovascularization and left ventricular function after myocardial infarction in a rat model. Basic Res. Cardiol. 103, 69-77. doi: 10.1007/s00395-007-0685-9

Schuster, M. D., Kocher, A. A., Seki, T., Martens, T. P., Xiang, G., Homma, S., et al. (2004). Myocardial neovascularization by bone marrow angioblasts results in cardiomyocyte regeneration. Am. J. Physiol. Heart Circ. Physiol. 287, H525H532. doi: 10.1152/ajpheart.00058.2004

Seminatore, C., Polentes, J., Ellman, D., Kozubenko, N., Itier, V., Tine, S., et al. (2010). The postischemic environment differentially impacts teratoma or tumor formation after transplantation of human embryonic stem cell-derived neural progenitors. Stroke 41, 153-159. doi: 10.1161/STROKEAHA.109.563015

Sen, S., Merchan, J., Dean, J., Ii, M., Gavin, M., Silver, M., et al. (2010). Autologous transplantation of endothelial progenitor cells genetically modified by adeno-associated viral vector delivering insulin-like growth factor-1 gene after myocardial infarction. Hum. Gene Ther. 21, 1327-1334. doi: 10.1089/hum. 2010.006

Senyo, S. E., Steinhauser, M. L., Pizzimenti, C. L., Yang, V. K., Cai, L., Wang, M., et al. (2013). Mammalian heart renewal by pre-existing cardiomyocytes. Nature 493, 433-436. doi: 10.1038/nature11682

Shake, J. G., Gruber, P. J., Baumgartner, W. A., Senechal, G., Meyers, J., Redmond, J. M., et al. (2002). Mesenchymal stem cell implantation in a swine myocardial infarct model: engraftment and functional effects. Ann. Thorac. Surg. 73, 19191925; discussion 1926.

Shiba, Y., Fernandes, S., Zhu, W. Z., Filice, D., Muskheli, V., Kim, J., et al. (2012). Human ES-cell-derived cardiomyocytes electrically couple and suppress arrhythmias in injured hearts. Nature 489, 322-325. doi: 10.1038/nature11317

Shintani, S., Kusano, K., Ii, M., Iwakura, A., Heyd, L., Curry, C., et al. (2006). Synergistic effect of combined intramyocardial CD34 + cells and VEGF2 gene therapy after MI. Nat. Clin. Pract. Cardiovasc. Med. 3(Suppl. 1), S123-S128. doi: 10.1038/ncpcardio0430

Shintani, S., Murohara, T., Ikeda, H., Ueno, T., Sasaki, K., Duan, J., et al. (2001). Augmentation of postnatal neovascularization with autologous bone marrow transplantation. Circulation 103, 897-903. doi: 10.1161/01.CIR.103.6.897

Sivarapatna, A., Ghaedi, M., Le, A. V., Mendez, J. J., Qyang, Y., and Niklason, L. E. (2015). Arterial specification of endothelial cells derived from human induced pluripotent stem cells in a biomimetic flow bioreactor. Biomaterials 53, 621-633. doi: 10.1016/j.biomaterials.2015.02.121

Smadja, D. M., Bieche, I., Helley, D., Laurendeau, I., Simonin, G., Muller, L., et al. (2007). Increased VEGFR2 expression during human late endothelial progenitor cells expansion enhances in vitro angiogenesis with up-regulation of integrin alpha(6). J. Cell Mol. Med. 11, 1149-1161. doi: 10.1111/j.1582-4934. 2007.00090.x 
Sturzu, A. C., and Wu, S. M. (2011). Developmental and regenerative biology of multipotent cardiovascular progenitor cells. Circ. Res. 108, 353-364. doi: 10.1161/CIRCRESAHA.110.227066

Suuronen, E. J., Veinot, J. P., Wong, S., Kapila, V., Price, J., Griffith, M., et al. (2006). Tissue-engineered injectable collagen-based matrices for improved cell delivery and vascularization of ischemic tissue using CD133 + progenitors expanded from the peripheral blood. Circulation 114, I138-I144. doi: 10.1161/ CIRCULATIONAHA.105.001081

Suzuki, H., Shibata, R., Kito, T., Yamamoto, T., Ishii, M., Nishio, N., et al. (2012). Comparative angiogenic activities of induced pluripotent stem cells derived from young and old mice. PLoS One 7:e39562. doi: 10.1371/journal.pone. 0039562

Takahashi, K., Tanabe, K., Ohnuki, M., Narita, M., Ichisaka, T., Tomoda, K., et al. (2007). Induction of pluripotent stem cells from adult human fibroblasts by defined factors. Cell 131, 861-872. doi: 10.1016/j.cell.2007.11.019

Tateishi-Yuyama, E., Matsubara, H., Murohara, T., Ikeda, U., Shintani, S., Masaki, H., et al. (2002). Therapeutic angiogenesis for patients with limb ischaemia by autologous transplantation of bone-marrow cells: a pilot study and a randomised controlled trial. Lancet 360, 427-435. doi: 10.1016/S01406736(02)09670-8

Trevelyan, J., Needham, E. W., Morris, A., and Mattu, R. K. (2005). Comparison of the effect of enalapril and losartan in conjunction with surgical coronary revascularisation versus revascularisation alone on systemic endothelial function. Heart 91, 1053-1057. doi: 10.1136/hrt.2004.036897

van Ramshorst, J., Antoni, M. L., Beeres, S. L., Roes, S. D., Delgado, V., Rodrigo, S. F., et al. (2011). Intramyocardial bone marrow-derived mononuclear cell injection for chronic myocardial ischemia: the effect on diastolic function. Circ. Cardiovasc. Imag. 4, 122-129. doi: 10.1161/CIRCIMAGING.110.957548

Wang, W., Lang, J. K., Suzuki, G., Canty, J. M. Jr., and Cimato, T. (2011). Statins enhance clonal growth of late outgrowth endothelial progenitors and increase myocardial capillary density in the chronically ischemic heart. PLoS One 6:e24868. doi: 10.1371/journal.pone.0024868

Wang, X. R., Zhang, M. W., Chen, D. D., Zhang, Y., and Chen, A. F. (2011). AMP-activated protein kinase rescues the angiogenic functions of endothelial progenitor cells via manganese superoxide dismutase induction in type 1 diabetes. Am. J. Physiol. Endocrinol. Metab. 300, E1135-E1145. doi: 10.1152/ ajpendo.00001.2011

Wingate, K., Floren, M., Tan, Y., Tseng, P. O., and Tan, W. (2014). Synergism of matrix stiffness and vascular endothelial growth factor on mesenchymal stem cells for vascular endothelial regeneration. Tissue Eng. Part A 20, 2503-2512. doi: 10.1089/ten.tea.2013.0249

Wollert, K. C., and Drexler, H. (2010). Cell therapy for the treatment of coronary heart disease: a critical appraisal. Nat. Rev. Cardiol. 7, 204-215. doi: 10.1038/ nrcardio. 2010.1

Wollert, K. C., Meyer, G. P., Muller-Ehmsen, J., Tschope, C., Bonarjee, V., Larsen, A. I., et al. (2017). Intracoronary autologous bone marrow cell transfer after myocardial infarction: the BOOST-2 randomised placebo-controlled clinical trial. Eur. Heart J. 38, 2936-2943. doi: 10.1093/eurheartj/ehx188

Writing Group Members, Mozaffarian, D., Benjamin, E. J., Go, A. S., Arnett, D. K., Blaha, M. J., et al. (2016). Heart disease and stroke statistics-2016 update: a report from the american heart association. Circulation 133, e38-360.

Wu, G., Rana, J. S., Wykrzykowska, J., Du, Z., Ke, Q., Kang, P., et al. (2009). Exercise-induced expression of VEGF and salvation of myocardium in the early stage of myocardial infarction. Am. J. Physiol. Heart Circ. Physiol. 296, H389-H395. doi: 10.1152/ajpheart.01393.2007
Xia, W. H., Li, J., Su, C., Yang, Z., Chen, L., Wu, F., et al. (2012). Physical exercise attenuates age-associated reduction in endothelium-reparative capacity of endothelial progenitor cells by increasing CXCR4/JAK-2 signaling in healthy men. Aging Cell 11, 111-119. doi: 10.1111/j.1474-9726.2011.00758.x

Xiong, Q., Hill, K. L., Li, Q., Suntharalingam, P., Mansoor, A., Wang, X., et al. (2011). A fibrin patch-based enhanced delivery of human embryonic stem cellderived vascular cell transplantation in a porcine model of postinfarction left ventricular remodeling. Stem Cells 29, 367-375. doi: 10.1002/stem.580

$\mathrm{Xu}, \mathrm{Q}$. (2006). The impact of progenitor cells in atherosclerosis. Nat. Clin. Pract. Cardiovasc. Med. 3, 94-101. doi: 10.1038/ncpcardio0396

Yamaguchi, J., Kusano, K. F., Masuo, O., Kawamoto, A., Silver, M., Murasawa, S., et al. (2003). Stromal cell-derived factor-1 effects on ex vivo expanded endothelial progenitor cell recruitment for ischemic neovascularization. Circulation 107, 1322-1328. doi: 10.1161/01.CIR.0000055313.77510.22

Yamanaka, S. (2012). Induced pluripotent stem cells: past, present, and future. Cell Stem Cell 10, 678-684. doi: 10.1016/j.stem.2012.05.005

Yang, C., Zhang, Z. H., Li, Z. J., Yang, R. C., Qian, G. Q., and Han, Z. C. (2004). Enhancement of neovascularization with cord blood CD133 + cell-derived endothelial progenitor cell transplantation. Thromb. Haemost. 91, 1202-1212. doi: 10.1160/TH03-06-0378

Zhang, H., Zhang, N., Li, M., Feng, H., Jin, W., Zhao, H., et al. (2008). Therapeutic angiogenesis of bone marrow mononuclear cells (MNCs) and peripheral blood MNCs: transplantation for ischemic hindlimb. Ann. Vasc. Surg. 22, 238-247. doi: 10.1016/j.avsg.2007.07.037

Zhang, L., Li, X., Yu, X., Li, Y., Sun, A., Huang, C., et al. (2017). Construction of vascularized pacemaker tissues by seeding cardiac progenitor cells and endothelial progenitor cells into Matrigel. Life Sci. 179, 139-146. doi: 10.1016/j. lfs.2017.05.007

Zhang, S., Ge, J., Zhao, L., Qian, J., Huang, Z., Shen, L., et al. (2007). Host vascular niche contributes to myocardial repair induced by intracoronary transplantation of bone marrow CD34 + progenitor cells in infarcted swine heart. Stem Cells 25, 1195-1203. doi: 10.1634/stemcells.2006-0605

Zhang, X., Guo, J. P., Chi, Y. L., Liu, Y. C., Zhang, C. S., Yang, X. Q., et al. (2012). Endothelin-induced differentiation of $\mathrm{Nkx} 2.5(+)$ cardiac progenitor cells into pacemaking cells. Mol. Cell. Biochem. 366, 309-318. doi: 10.1007/s11010-0121309-8

Zhang, X. Y., Su, C., Cao, Z., Xu, S. Y., Xia, W. H., Xie, W. L., et al. (2014). CXCR7 upregulation is required for early endothelial progenitor cell-mediated endothelial repair in patients with hypertension. Hypertension 63, 383-389. doi: 10.1161/HYPERTENSIONAHA.113.02273

Zhang, Z., Dong, J., Lobe, C. G., Gong, P., Liu, J., and Liao, L. (2015). CCR5 facilitates endothelial progenitor cell recruitment and promotes the stabilization of atherosclerotic plaques in ApoE-/- mice. Stem Cell Res. Ther. 6:36. doi: 10.1186/s13287-015-0026-0

Conflict of Interest Statement: The authors declare that the research was conducted in the absence of any commercial or financial relationships that could be construed as a potential conflict of interest.

Copyright (C) 2018 Hou and Li. This is an open-access article distributed under the terms of the Creative Commons Attribution License (CC BY). The use, distribution or reproduction in other forums is permitted, provided the original author(s) and the copyright owner(s) are credited and that the original publication in this journal is cited, in accordance with accepted academic practice. No use, distribution or reproduction is permitted which does not comply with these terms. 